
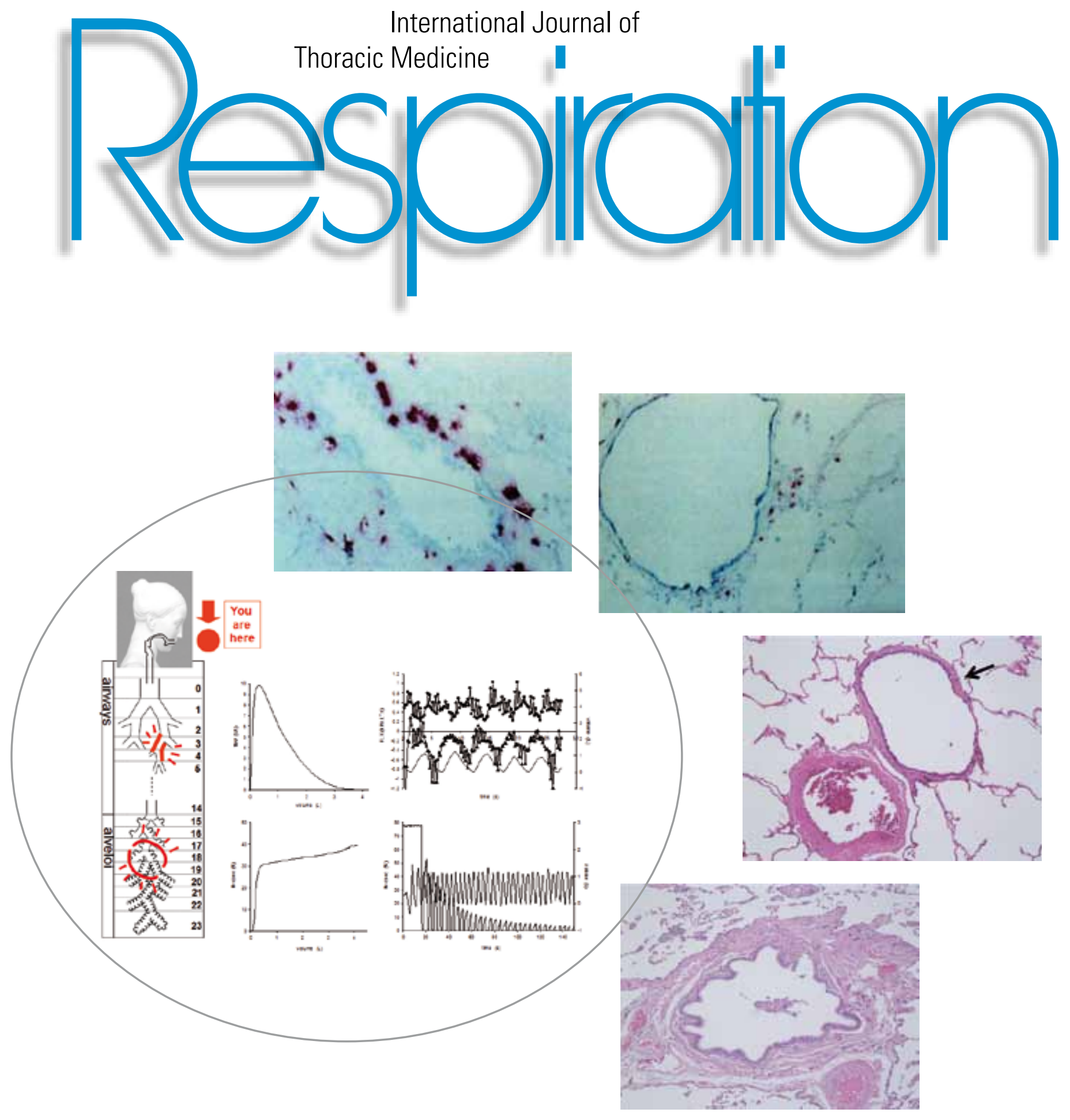

S. Karger
Medical and Scientific Publishers Basel · Freiburg · Paris .

London - New York .

New Delhi · Bangkok · Beijing

Tokyo $\cdot$ Kuala Lumpur .

Singapore $\cdot$ Sydney SCHWEIZERISCHE GESELLSCHAFT
FER PNEUMOLOGIE
SOCIÉTÉ SUISE DENELOGIE
SOCIETA SVZZZREA DI PNEUMOLOGIA
European Association for 


\section{LUNGENEMPHYSEM DURCH ALPHA-1?}

Daran denken - testen - therapieren!1

1 American Thoracic Society / European Respiratory Society: Standards in Diagnosis and Treatment in Patients with Alpha-1-Antitrypsin Deficiency. Am J Respir Crit Care Med 2003 (168).

Prolastin $^{\circledR}$ Zusammensetzung: Eine Durchstechflasche enthält lyophilisierte Humanplasmaprotein fraktion entsprechend $1000 \mathrm{mg}$ funktionellem Alpha-1-Proteinaseninhibitor. Die Trockensubstanz ist mit $40 \mathrm{ml}$ Wasser für Injektionszwecke aufzulösen. $1 \mathrm{ml}$ der gebrauchsfertigen Lösung enthält 25 mg Alpha-1 Proteinaseninhibitor. Pharmazeutische Form: Durchstechflasche mit Lösung zur Infusion. Indikation: Zur Dauersubstitutionstherapie bei Alpha-1-Proteinaseninhibitormangel mit progredientem Lungenemphysem bei Patienten mit Proteinaseinhibitor-Phänotyp (Z, Z), (Z, Null), (Null, Null) oder (S, Z). Eine erfolgreiche Verlangsamung der Emphysemprogredienz wird am besten bei einer mittelgradigen Funktionseinschränkung $\left(\mathrm{FEV}_{1}\right)$ der Lunge erreicht. Anwendung: Soweit nicht anders verordnet, reicht eine wöchentliche Dosis von 60 mg Alpha-1-Proteinaseninhibitor/kg Körpergewicht als Kurzinfusion aus, um den Alpha-1 Proteinaseninhibitorspiegel im Serum ständig über $80 \mathrm{mg} / \mathrm{dl}$ zu halten. Dieser Wert gilt als Mindestwert zum Schutz gegen eine weitere Verschlechterung des Lungenemphysems. Die gebrauchsfertige Lösung ist langsam intravenös mit einem geeigneten Infusionsbesteck zu infundieren. Die Infusionsgeschwindigkeit sollte $0,08 \mathrm{ml} / \mathrm{kg}$ Körpergewicht pro Minute nicht überschreiten. Kontraindikationen: IgA-Mangel mit Antikörpern gegen IgA, dekompensiertes Cor pulmonale. Vorsichtsmassnahmen: Im Falle einer schweren Überempfindlichkeitsreaktion (mit Blutdruckabfall $<90 \mathrm{~mm} \mathrm{Hg}$. Atemnot bis hin zum anaphylaktischen Schock) ist Prolastin sofort abzusetzen und eine entsprechende Behandlung, gegebenenfalls eine Schocktherapie, einzuleiten. Da Prolastin zu einer kurzfristigen Erhöhung des Blutvolumens führen kann, ist be Patienten mit schwerer Herzinsuffizienz besondere Vorsicht geboten. Schwangerschaft/Stillzeit: Es liegen keine Untersuchungen vor. Bei der Anwendung während der Schwangerschaft oder der Stillperiode ist Vorsicht geboten. Unerwünschte Wirkungen: Selten $(0,01-0,1 \%)$ wurden die folgenden Ereignisse beobachtet: vorübergehende Blutdruckerhöhung, Überempfindlichkeitsreaktionen gegen menschliche Plasmaproteine. Interaktionen: keine bekannt. Pharmazeutische Angaben: Trockensubstanz nicht über $25^{\circ} \mathrm{C}$ lagern. Nicht einfrieren. Die gebrauchsfertige Lösung darf nur innerhalb von 3 Stunden nach der ¿ Herstellung verwendet werden. Abgabekategorie B. Zulassungsinhaberin: Crucell Switzerland AG, Rehhagstrasse 79, CH-3018 Bern. Die vollständigen Informationen - Crucell $\begin{aligned} & \text { finden sich in der Fachinformation (Arzneimittelkompendium, } \\ & \text { www.kompendium.ch). Stand April } 2010\end{aligned}$ 
Official Journal of

SCHWEIZERISCHE GESELLSCHAFT

FÜR PNEUMOLOGIE

SOCIÉTÉ SUISSE DE PNEUMOLOGIE

SOCIETÀ SVIZZERA DI PNEUMOLOGIA

European Association for

Bronchology and

Interventional Pulmonology

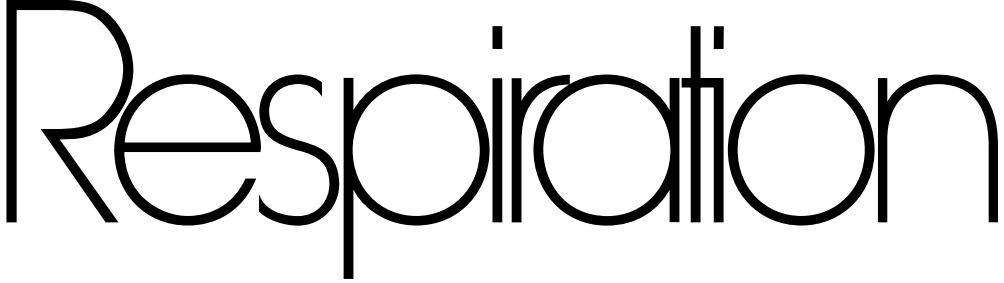

International Journal of Thoracic Medicine

Founded 1944 as 'Schweizerische Zeitschrift für Tuberkulose und Pneumonologie' by E. Bachmann, M. Gilbert, F. Häberlin, W. Löffler, P. Steiner and E. Uehlinger, continued 1962-1967 as 'Medicina Thoracalis', as of 1968 as 'Respiration', H. Herzog (1962-1997)

\section{Editor-in-Chief}

C.T. Bolliger, Cape Town

\section{Associate Editors}

I.M. Adcock, London

K.E. Bloch, Zürich

A. Boehler, Zürich

D.E. Bouros, Alexandroupolis

G. Colice, Washington, D.C.

V. Cottin, Lyon

C. Dooms, Leuven

E. Eber, Graz

S. Gasparini, Ancona

P. Gustafsson, Skövde
J. Hammer, Basel

F.J.F. Herth, Heidelberg

J. Johnston, Vancouver, B.C.

C. Kroegel, Jena

F. Kummer, Vienna

P.N. Mathur, Indianapolis, Ind.

M. Miravitlles, Barcelona

J. Müller-Quernheim, Freiburg

L.P. Nicod, Lausanne

M. Noppen, Brussels
D. Olivieri, Parma

C. Page, London

W. Randerath, Solingen

S. Siddiqui, Leicester

T. Terashima, Ichikawa

O.S. Usmani, London

S. van Eeden, Vancouver, B.C.

K. Yasufuku, Toronto, Ont.

\section{Editorial Board}

P.J. Barnes, London

X. Basagana Flores, Barcelona

S. Bilaceroglu, Izmir

E. Brambilla, Grenoble

P. Camus, Dijon

M. Cazzola, Rome

A. Chetta, Parma

P.N. Chhajed, Mumbai

U. Costabel, Essen

K. Dorrington, Oxford

A. Foresi, Sesto San Giovanni

M.E. Froudarakis, Alexandroupolis
G. Hoheisel, Leipzig

M. Humbert, Clamart

M. Kneussl, Vienna

C.F. Koegelenberg, Cape Town

N. Künzli, Basel

J.G. Mastronarde, Columbus, Ohio

A.R.L. Medford, Bristol

A. Mehta, Basel

L.E. Nery, São Paulo

A. Palla, Pisa

H.-B. Ris, Lausanne

J.L. Robotham, Seattle, Wash.
F. Rodriguez-Panadero, Sevilla

I. Rubinstein, Chicago, Ill.

T. Schaberg, Rotenburg

F.C. Sciurba, Pittsburgh, Pa.

M. Solèr, Basel

A.O. Soubani, Detroit, Mich.

S. Spiro, London

T.G. Sutedja, Amsterdam

E.R. Sutherland, Denver, Colo.

H. Wirtz, Leipzig

E.F.M. Wouters, Maastricht
Printed in Switzerland on acid-free and non-aging paper (ISO 9706) by Reinhardt Druck, Base
Appears monthly: 2 volumes per year (12 issues) 


\section{Respiration}

\section{Submission}

Manuscripts written in English should be submitted using the online submission website at:

\section{www.karger.com/res}

or as an e-mail attachment (the preferred word-processing package is MS-Word) to the Editorial Office:

\section{res@karger.ch}

Professor C.T. Bolliger

S. KARGER AG

Editorial Office 'Respiration'

PO Box

CH-4009 Basel (Switzerland)

All manuscripts must be accompanied by a covering letter signed by all authors. Assurance should be given that the manuscript is not under simultaneous consideration by any other publication. The preferred word processing package is Word for Windows ${ }^{\circ}$. Presentation of manuscripts should conform with the Uniform Requirements for Manuscripts Submitted to Biomedical Journals (see N Engl J Med 1997;336:309-315).

\section{Conditions}

All manuscripts are subject to an editorial process in volving the Editor-in-Chief, an Associate Editor and reviewers. Notification can be expected within two months from the date of receipt. Submission of an article for publication implies the transfer of the copyright from the author to the publisher upon acceptance. Accepted papers become the permanent property of 'Respiration' and may not be reproduced by any means, in whole or in part, without the written consent of the publisher. It is the author's responsibility to obtain permission to reproduce illustrations, tables, etc. from other publications.

Clinical Trials: In accordance with the recommendations of the International Committee of Medical Journal Editors, the journal requires that all clinical trials having commenced on or after 1 July 2005 be registered in a public trial registry accessible free of charge. Please consult http://www.icmje.org/index.html\#clin trials for further details. 'Respiration' has implemented the expanded definition stating that 'any research study that prospectively assigns human participants or groups of humans to one or more health-related interventions to evaluate the effects on health outcomes' Health-related interventions include any intervention used to modify a biomedical or health-related outcome (for example, drugs, surgical procedures, devices, behavioral treatments, dietary interventions, and process-of-care changes). Health outcomes include any biomedical or health-related measures obtained in patients or participants, including pharmacokinetic measures and adverse events. Purely observational studies (those in which the assignment of the medical intervention is not at the discretion of the investigator) will not require registration.
The journal consists of the following sections:

\author{
1. Thematic Review Series \\ 2. Editorials \\ 3. Clinical Investigations \\ 4. Interventional Pulmonology \\ 5. Basic Science Investigations \\ 6. New Drugs in Respiratory Medicine \\ 7. Technical Notes \\ 8. The Eye Catcher \\ 9. Novel Insights from Clinical Practice \\ 10. What Is Your Diagnosis? \\ 11. Reviews \\ 12. Guidelines \\ 13. The Opinion Corner \\ 14. Clinico-Pathological Conferences \\ 15. Letters to the Editor \\ 16. Congress Calendar
}

Reviews: Invited reviews, if accepted, are not subject to page charges. Unsolicited reviews may also be submit ted for consideration.

Letters addressed to the Editor are encouraged if they directly concern articles previously published in this journal and clinical subjects related to the matters discussed. The editor reserves the right to submit copies of such letters to the authors of the articles concerned prior to publication in order to permit them to respond in the same issue of the journal. But letters on genera scientific or medical subjects in respiratory medicine are also welcome. Letters to the Editor should be no longer than one printed page.

Eye Catchers: Maximum 1 printed page. Text may not exceed 250 words to allow sufficient space for pictoria material, which is the main object of an Eye Catcher. Maximum 2 references and 2-5 keywords.

Novel Insights from Clinical Practice (formerly Case Reports): Maximum 7 authors. The publication space available for case reports is very limited. The journal only considers case reports with significant new insights or with an extremely unusual and memorable course. Highlighted boxes containing one or two bullet points on 'Established facts' (what is already known) and 'Novel insights' (what new information has been gained) are required and should be placed on the first page of the report. These should be selected so as to reinforce the novelty of the clinical observation. The text per box should be limited to 1-2 very short sentences. The manuscript should be presented with an abstract (unstructured, max. 200 words), followed by introduction, case report and discussion. Maximum 3 figures.

What Is Your Diagnosis?: Select catchy title not disclosing the diagnosis. Page 1: Case report and 1-2 illustrations and the question 'What Is Your Diagnosis'. Page 2: The diagnosis followed by a short description of what diagnostic procedures were done to reach the diagnosis and the discussion with references. Maximum 15 references and include 3-5 key words.

Guidelines: Consensus Guidelines are welcome from working groups to provide guidance in key and emerging areas in all fields of respiratory medicine. Such guidelines are also subject to a reviewing process.
Patient Consent: This is required for ALL articles containing personal information about the patient submitted for publication in the following sections:

Novel Insights from Clinical Practice

What Is Your Diagnosis?

Eye Catcher

Signed patient consent must be obtained from the patient, guardian or next of kin (or a statement that the patient was not alive at the time of writing) and submitted along with the manuscript. For Patient Consent Form see www.karger.com/res_Guidelines

\section{Arrangement}

Pages should be numbered throughout the manuscript text.

Title page: The first page of each paper should indicate the title, the authors' names, the institute where the work was conducted, and a short title for use as running head.

Full address: The exact postal address of the corresponding author complete with postal code must be given at the bottom of the title page. Please also supply phone and fax numbers, as well as e-mail address.

Key words: Please supply 3-10 key words in English that reflect the content of the paper.

Abstract: Each paper needs an abstract of up to 250 words. Abstracts of papers submitted for publication in the sections Clinical Investigations, Basic Science Investigations, Interventional Pulmonology, and Technical Notes should be structured as follows:

Background: What is the major motive that prompted the study?

Objectives: What is the purpose of the study?

Methods: How was the study done?

Results: $\quad$ Most important findings.

Conclusions: Most important conclusions.

\section{Introduction}

What is the main question? State your considerations leading to the formulation of this question.

\section{Material and Methods}

Prior approval of an Institutional Review Board (IRB) is required for all investigations involving human subjects and animals. Animal experimentation must be performed according to the Helsinki Declaration.

Study design: Provide a short survey of the tests or experiments. Include the independent variable(s) manipulated, the dependent variable(s) measured and all controls.

Methods: Describe methods and apparatus in detail Provide references and brief description of methods already published. Identify drugs and chemicals, including generic name, dosage and administration. Describe the pre-study condition of patients or animals.

Analysis: Define the variables. Use statistical analysis that is appropriate for the study. Describe statistical methods used for each analysis; provide references for tests that are not well known.

\section{KARGER}

Fax +4161306 1234 E-Mail karger@karger.ch www.karger.com
(C) 2012 S. Karger AG, Base 


\section{Results}

A concise report of important results only. Use figures and tables for the presentation of data; summarize the most important observations in the text. Start and end dates of the study must be indicated (from ... to, preferably exact dates, but at least months and year[s]).

\section{Discussion}

Summarize main results and make sure you can answer the question asked in the introduction, briefly supporting the answer with the relevant results. Explain and defend the answer, comment on contradictory or unexpected results and discrepancies with previous findings. Elaborate on new and important aspects of the study.

\section{Acknowledgements}

Use this section to name persons who have contributed to the article, but whose contributions do not justify authorship.

\section{Footnotes}

Avoid footnotes. When essential, they are numbered consecutively and typed at the foot of the appropriate page.

\section{Tables and IIlustrations}

Tables and illustrations (both numbered in Arabic numerals) should be prepared on separate sheets. Tables require a heading and figures a legend, also prepared on a separate sheet. Due to technical reasons, figures with a screen background should not be submitted. When possible, group several illustrations in one block for reproduction (max. size $180 \times 223 \mathrm{~mm}$ ) or provide crop marks. Each illustration must be labelled with its number and the first author's name. $\mathrm{B} / \mathrm{w}$ half-tone and color illustrations must have a final resolution of $300 \mathrm{dpi}$ after scaling, line drawings one of $800-1,200$ dpi. Figure files must not be embedded in a document file but submitted separately (see detailed instructions at www.karger.com/res/).

\section{Color illustrations}

Online edition: Color illustrations are reproduced free of charge. In the print version, the illustrations are reproduced in black and white. Please avoid referring to the colors in the text and figure legends.

Print edition: Up to 6 color illustrations per page can be integrated within the text at CHF 800.- per page.

\section{References}

In the text identify references by Arabic numerals [in square brackets]. Material submitted for publication but not yet accepted should be noted as 'unpublished data' and not be included in the reference list. The list of references should include only those publications which are cited in the text. Do not alphabetize; number references in the order in which they are first mentioned in the text. The surnames of the authors followed by initials should be given. There should be no punctuation other than a comma to separate the authors. Preferably, please cite all authors. Abbreviate journal names according to the Index Medicus system. Also see International Committee of Medical Journal Editors: Uniform requirements for manuscripts submitted to biomedical journals (www.icmje.org).

Examples

(a) Papers published in periodicals: Sun J, Koto H, Chung KF: Interaction of ozone and allergen challenges on bronchial responsiveness and inflammation in sensitised guinea pigs. Int Arch Allergy Immunol 1997;112:191-195.

(b) Papers published only with DOI numbers:

Theoharides TC, Boucher W, Spear K: Serum interleukin-6 reflects disease severity and osteoporosis in mastocytosis patients. Int Arch Allergy Immunol DOI: $10.1159 / 000063858$

(c) Monographs: Matthews DE, Farewell VT: Using and Understanding Medical Statistics, ed 3, revised. Basel, Karger, 1996.

(d) Edited books: Parren PWHI, Burton DR: Antibodies against HIV-1 from phage display libraries: Mapping of an immune response and progress towards antiviral immunotherapy; in Capra JD (ed): Antibody Engineering. Chem Immunol. Basel, Karger, 1997, vol 65, pp 18-56.

Reference Management Software: Use of EndNote is recommended for easy management and formatting of citations and reference lists.

SI Units

Since the United States of America and other countries outside Europe where 'Respiration' is read have not accepted the SI System, authors using SI Units should add the conventional units in parentheses, for example: $\mathrm{pO}_{2}=10 \mathrm{kPa}(75 \mathrm{~mm} \mathrm{Hg})$.

\section{Digital Object Identifier (DOI)}

S. Karger Publishers supports DOIs as unique identifiers for articles. A DOI number will be printed on the title page of each article. DOIs can be useful in the future for identifying and citing articles published online without volume or issue information. More information can be found at www.doi.org.

\section{Supplementary Material}

Supplementary material is restricted to additional data that are not necessary for the scientific integrity and conclusions of the paper. Please note that all supplementary files will undergo editorial review and should be submitted together with the original manuscript. The Editors reserve the right to limit the scope and length of the supplementary material. Supplementary material must meet production quality standards for Web publication without the need for any modification or editing. In general, supplementary files should not exceed $10 \mathrm{MB}$ in size. All figures and tables should have titles and legends and all files should be supplied separately and named clearly. Acceptable files and formats are: Word or PDF files, Excel spreadsheets (only if the data cannot be converted properly to a PDF file), and video files (.mov, .avi, .mpeg)

\section{Page Charges}

There are no page charges for papers of 4 or fewer printed pages (including tables, illustrations and references). Each additional complete or partial page is charged to the author at CHF 325.-. The allotted size of a paper is equal to approx. 12 manuscript pages (including tables, illustrations and references).

\section{Author's Choice ${ }^{\mathrm{TM}}$}

Karger's Author's Choice ${ }^{\mathrm{TM}}$ service broadens the reach of your article and gives all users worldwide free and full access for reading, downloading and printing at www.Karger.com. The option is available for a onetime fee of CHF 3000.-, which is a permissible cost in grant allocation. More information can be found at www.karger.com/authors_choice.

\section{NIH-Funded Research}

The U.S. National Institutes of Health (NIH) mandates under the NIH Public Access Policy that final, peer-reviewed manuscripts appear in its digital database within 12 months of the official publication date. As a service to authors, Karger submits the final version of your article on your behalf to PubMed Central. For those selecting our premium Author's Choice ${ }^{\mathrm{TM}}$ service, we will send your article immediately upon publishing, accelerating the accessibility of your work without the usual embargo. More details on NIH's Public Access Policy are available at http://publicaccess.nih.gov/policy.htm

\section{Self-Archiving}

Karger permits authors to archive their pre-prints (i.e. pre-refereeing) or post-prints (i.e. final draft post-refereeing) on their personal or institution's servers, provided the following conditions are met: Articles may not be used for commercial purposes, must be linked to the publisher's version, and must acknowledge the publisher's copyright. Authors selecting Karger's Author's Choice ${ }^{\mathrm{TM}}$ feature, however, are also permitted to archive the final, published version of their article, which includes copyediting and design improvements as well as citation links.

\section{Proofs}

Unless indicated otherwise, proofs are sent to the corresponding author and should be returned with the least possible delay. Alterations other than the correction of printer's errors are charged to the author.

\section{E-pub First}

All articles are published electronically ahead of print with a DOI number and are supplemented later with the definite reference of the printed version. The articles become available immediately after the authors' approval to publication, with the added advantage of being citable much earlier than in print. Authors can influence the time of appearance by promptly returning the proofs.

\section{Reprints}

Order forms and a price list are sent with the proofs. Orders submitted after the issue is printed are subject to considerably higher prices.

\section{Financial Disclosure and Conflicts of Interest}

Authors must disclose any and all financial involvement in any organization with a direct financial interest in the subject discussed in the submitted manuscript. Any conflict of interest for a given manuscript must be dealt with according to the statement of the International Committee of Medical Journal Editors (the 'Vancouver Group') (Lancet 1993;341:742).

\section{Further Information}

For any further details please contact the Editorial Department 'Respiration', Fax +41613061434.

\section{KARGER}

Fax +41 613061234 E-Mail karger@karger.ch www.karger.com 
ISSN Print Edition: 0025-7931

ISSN Online Edition: 1423-0356

Journal Homepage: www.karger.com/res

Publication Data: 'Respiration' is published 12 times a year. Volumes 83 and 84, each with 6 issues, appear in 2012 .

Copyright: (c) 2012 S. Karger AG, Basel (Switzerland) All rights reserved. No part of this publication may be translated into other languages, reproduced or utilized in any form or by any means, electronic or mechanical, including photocopying, recording, microcopying, or by any information storage and retrieval system, with out permission in writing from the publisher or, in the case of photocopying, direct payment of a specified fee to the Copyright Clearance Center.

Disclaimer: The statements, opinions and data contained in this publication are solely those of the individual authors and contributors and not of the publisher and the editor(s). The appearance of advertisements in the journal is not a warranty, endorsement, or approval of the products or services advertised or of their effectiveness, quality or safety. The publisher and the editor(s) disclaim responsibility for any injury to persons or property resulting from any ideas, methods, instructions or products referred to in the content or advertisements.
Subscription Rates: Subscriptions run for a full calendar year. Prices are given per year. Personal subscription:

Print or Online

CHF 163.-

Print+Online combined

EUR 130.-

CHF 259.-

USD 158.00

EUR 206.-

USD 252.00

postage and handling (added to print and print+online)

CHF 81.60 Europe, CHF 120.- Overseas

EUR 62.40

USD 112.80

Institutional subscription:

Print or Online

Print+Online combined

CHF 2398.-

EUR 1918.-

CHF 2638.

EUR 2110.

(added to print and print+online)

CHF 102.- Europe, CHF 150.- Overseas

EUR 78.-

USD 141.00

Airmail surcharge: CHF 102.- / USD 96.00

Discount subscription prices:

Please enquire about reduced rates for members of related societies.

EABIP: subscription included in membership fee.
Back Volumes and Single Issues: Information on availability and prices of single print issues and print or electronic back volumes can be obtained from Customer Service at service@karger.ch.

Bibliographic Indices: This journal is regularly listed in bibliographic services, including Current Contents ${ }^{\otimes}$ and PubMed/MEDLINE.

Photocopying: This journal has been registered with the Copyright Clearance Center (CCC), as indicated by the code appearing on the first page of each article. For readers in the US, this code signals consent for copying of articles for personal or internal use, or for the personal or internal use of specific clients, provided that the stated fee is paid per copy directly to

Copyright Clearance Center Inc.

222 Rosewood Drive

Danvers, MA 01923 (USA)

A copy of the first page of the article must accompany payment. Consent does not extend to copying for general distribution, for promotion, for creating new works, or for resale. In these cases, specific written permission must be obtained from the copyright owner,

S. Karger AG, P.O. Box

CH-4009 Basel (Switzerland).
Subscription Orders:

Orders can be placed at agencies,

bookstores, directly with the Publisher

\section{S. Karger AG}

Medical and Scientific Publishers

P.O. Box

CH-4009 Basel

Switzerland

(for courier services only:

Allschwilerstrasse 10

CH-4055 Basel)

$\mathrm{t}:+41613061111$

f: +41613061234

e: karger@karger.ch

w: www.karger.com

Change of Address:
Both old and new address should be sent

to the subscription source. or further Karger offices

or representatives:

Germany

S. Karger GmbH

Postfach

79095 Freiburg

Deutschland

(Hausadresse: Wilhelmstrasse 20A,

79098 Freiburg)

$\mathrm{t}: \quad+49761452070$

f: $\quad+497614520714$

e: information@karger.de

w: www.karger.de

Japan

Karger Japan, Inc

Shiba Daimon Asahi Bldg. $2 \mathrm{~F}$

1-2-23 Shiba Daimon

Minato-ku

Tokyo 105-0012

Japan

t: +81364356242

f: +81364356244

e: publisher@karger.jp

w: www.karger.jp
USA

S. Karger Publishers, Inc

26 West Avon Road

P.O. Box 529

Unionville, CT 06085

USA

Toll free: +18008285479

t: +18606757834

f. +18606757302

e: karger@snet.net

France

Librairie Médi-Sciences Sarl

36, bd de Latour-Maubourg

75007 Paris

France

t: $+33(0) 145514258$

f: $+33(0) 145560780$

e: librairie@medi-sciences.fr

w: www.medi-sciences.fr

Gulf Council Countries, Iran,

Middle East, North Africa, Turkey

Trans Middle East International

Distribution Co. Ltd. (KaSha)

168 B, King Abdullah the 2nd Street

Daboog Building 2nd Floor

Daboog Area

P.O. Box 2376

Amman 11953

Jordan

t: +96265153467

f: +96265411336

e: info@kasha.cc

w: www.KaShaonline.com
South East Asia, China and Taiwan

Karger Regional Office (Malaysia)

CEO Suite Kuala Lumpur

Quill 7, 27th Floor

Jalan Stesen Sentral 5

KL Sentral

Kuala Lumpur 50470

Malaysia

t: +60327766803

f: +60327766999

e: service@karger.cn; r.chew@karger.cn

\section{Karger China}

10th Floor, Twin Towers (East)

B12 Jianguomenwai Avenue

Beijing 100022

China

t: +861051235033

f: +861051235122

e: service@karger.cn; r.chew@karger.cn

w: www.karger.cn

India, Bangladesh, Sri Lanka

Medscience India

Plot No. 17, Yusuf Sarai Market

B.L. Glass Building, 2nd Floor

Sri Aurobindo Marg

New Delhi 110016

India

t: +911146029633

f: +911146029634

c: +919891052128

e: medsci.india@gmail.com

\section{KARGER}

Fax +41 613061234

E-Mail karger@karger.ch

www.karger.com
(C) 2012 S. Karger AG, Basel

The Journal Home Page is available at:

www.karger.com/res 


\section{Contents}

See the journal website for contents

KARGER Basel $\bullet$ Freiburg $\cdot$ Paris $\bullet$ London $\bullet$ New York $\cdot$ New Delhi $•$ Bangkok Beijing $\cdot$ Tokyo $\cdot$ Kuala Lumpur $\cdot$ Singapore $\bullet$ Sydney 


\section{Onbrez' Breezhaler}

\section{Die schnell wirksame}

\section{Wirkt stark. Wirkt schnell. Wirkt 24 Stunden.}

Kurzfachinformation Onbrez ${ }^{\oplus}$ Breezhaler ${ }^{\oplus}$ Z: Wirkstoff: Indacaterol. Hilfsstoffe: Lactosum monohydricum, excip. pro caps., gelatina (Kapselhülle). I: Bronchialerweiternde Erhaltungstherapie der

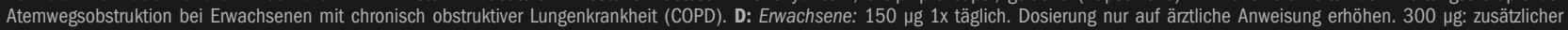
klinischer Nutzen in Hinblick auf Kurzatmigkeit, v. a. bei Patienten mit schwerer COPD. Höchstdosis: $300 \mu \mathrm{g} 1 \mathrm{x}$ täglich. Jeden Tag zur gleichen Tageszeit anwenden. Spezielle Patientengruppen: Keine Dosisanpassung bei älteren Patienten, leichter und moderater Leberfunktionsstörung oder Nierenfunktionsstörung. Keine Daten mit schwerer Leberfunktionsstörung vorhanden. Anwendung: nur per orale

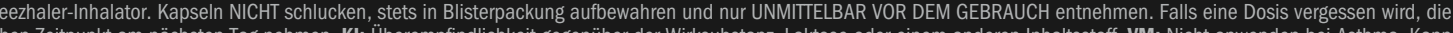
näcste Dum üblichen Zeitpunkt am nächsten Tag nehmen. KI: Überempfindlichkeit gegenüber der Wirksubstanz, Laktose oder einem anderen Inhaltsstoff. VM: Nicht anwenden bei Asthma. Kann wie andere Inhalationstherapien möglicherweise lebensgefährlichen paradoxen Bronchospasmus auslösen. Bei Auftreten unverzüglich absetzen und Alternativbehandlung einleiten. Verschlechterung der Krankheit: Neubeurteilung des Patienten und der Behandlung. Systemische Auswirkungen: Wie andere beta2-adrenergen Agonisten mit Vorsicht einsetzen bei Herzkreislauferkrankungen, v. a. bei Koronarinsuffizienz, Herzhythmusstörungen und Bluthochdruck, Epilepsie oder Thyreotoxikose und bei ungewöhnlichem Ansprechen auf beta2-adrenerge Agonisten. Wie andere beta2-adrenerge Agonisten könnte Indacaterol das Herzkreislaufsystem klinisch relevant beeinflussen (Anstieg der Pulsfrequenz, des Blutdrucks und/oder Symptome). Veränderungen des EKG-Musters. Beta2-adrenerge Agonisten können signifikante Hypokaliämie verursachen, die unenwünschte kardiovaskuläre Wirkungen verursachen kann. Bei schwerer COPD kann sich Hypokaliämie durch Hypoxie und Begleitbehandlung verstärken, was Anfälligkeit für Herzrhythmusstörungen erhöhen könnte. In klinischen Studien sind selten klinisch beachtenswerte Veränderungen des Blutzuckers aufgetreten. Nicht gemeinsam anwenden mit anderen lang wirkenden beta2-adrenergen Agonisten bzw. Arzneimitteln, die solche enthalten. IA: Nicht gleichzeitig anwenden mit Arzneimitteln, die Verlängerung des QTc-Intervalls bewirken. Vorsichtig bei Behandlung mit MAO-Hemmern oder trizyklischen Antidepressiva. Zusätzliche Verabreichung sympathikomimetischer Substanzen kann unerwünschte kardiovaskuläre Wirkungen verstärken. Gleichzeitige Verabreichung von L-Dopa, L-Thyroxin und Oxytocin kann kardiale Toleranz gegenüber $\beta 2$-Sympathomimetika negativ beeinflussen. Gleichzeitige Anwendung anderer Sympathomimetika könnte unerwünschte Wirkungen verstärken. Gleichzeitige Behandlung mit Methylxanthin-Derivaten, Steroiden oder nicht kaliumsparenden Diuretika könnte durch beta2-adrenerge Agonisten hervorgerufene Hypokaliämie $\underset{\Sigma}{\Sigma}$ verstärken. Nicht gemeinsam mit beta-adrenergen Blockern verabreichen, ausser dies ist klinisch zwingend begründet. Inhibierung der Hauptkomponenten der Indacaterol Clearance, CYP3A4 und P-Glykoprotein (P-gp) erhöht systemische Wirkstoffkonzentration. UW: Sehr häufig: Nasopharyngitis (16.7\%). Häufig: Infektionen der oberen Atemwege, Sinusitis, Pneumonie, Husten, Pharyngolaryngealer Schmerz, Rhinorrhoe, Kopfschmerzen, Parästhesie, Muskelkrämpfe, Myalgie, Nackenschmerzen,
Vorhofflimmern. Beschwerden im Brustkorb, Diabetes mellitus. Gelegentlich: Angina pectoris. Selten und sehr selten: s. Kompendium. P: 150 ug bzw. 300 ug: Packung zu 30 Hartkapseln, 1 Inhalator. Verkaufskategorie: (B). Weitere Informationen entnehmen Sie bitte dem Arzneimittel-Kompendium der Schweiz ${ }^{\oplus}$. Novartis Pharma Schweiz AG, Monbijoustrasse 118, Postfach, 3001 Bem, Tel. 0313775111.

1 GOLD - Global Initiative for Chronic Obstructive Lung Disease: Global Strategy for thee Diagnosis, Management, and Prevention of Chronic Obstructive Pulmonary Disease, 2010; www. goldcopd. org. 2 Onbrez ${ }^{\circledR}$ Breezhaler ${ }^{\oplus}$ Fachinformation, www.documed.ch, Stand der Information Mai 2010.

*Preisstand Spezialitätenliste Februar 2012

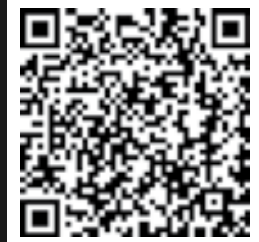

Breezhaler Instruktionsvideo 


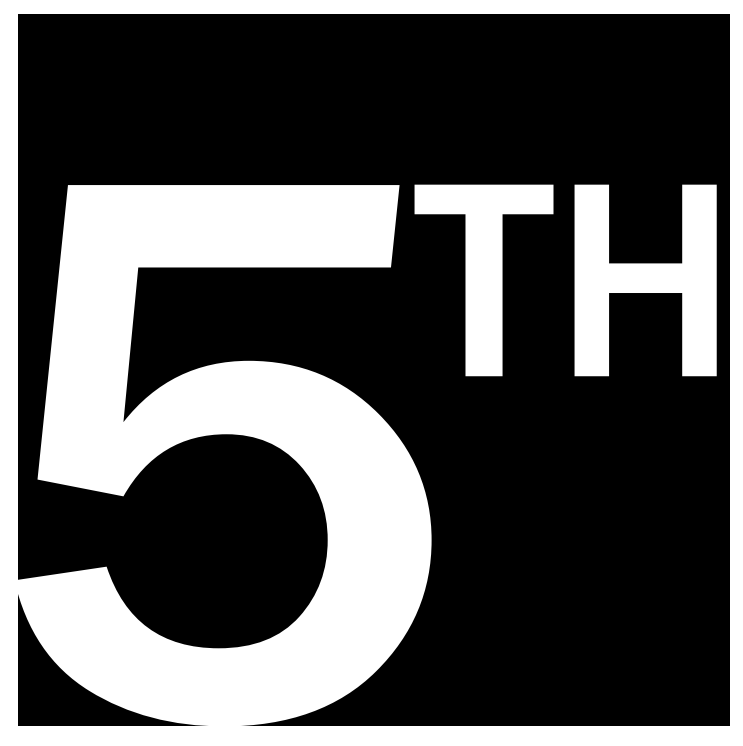

INTERNATIONAL MEETING ON PULMONARY RARE DISEASES AND ORPHAN DRUGS

PRESIDENT

\section{SERGIO HARARI}

MILANO - ITALY

FEBRUARY 8-9, 2013

ORGANIZING SECRETARIAT VICTORY PROJECT CONGRESSI Via C. Poma, 2 - 20129 Milan, Italy Tel. +3902 89053524

Fax +3902 201395 info@victoryproject.it

\section{WWW.PULMONARYRAREDISEASES.COM}




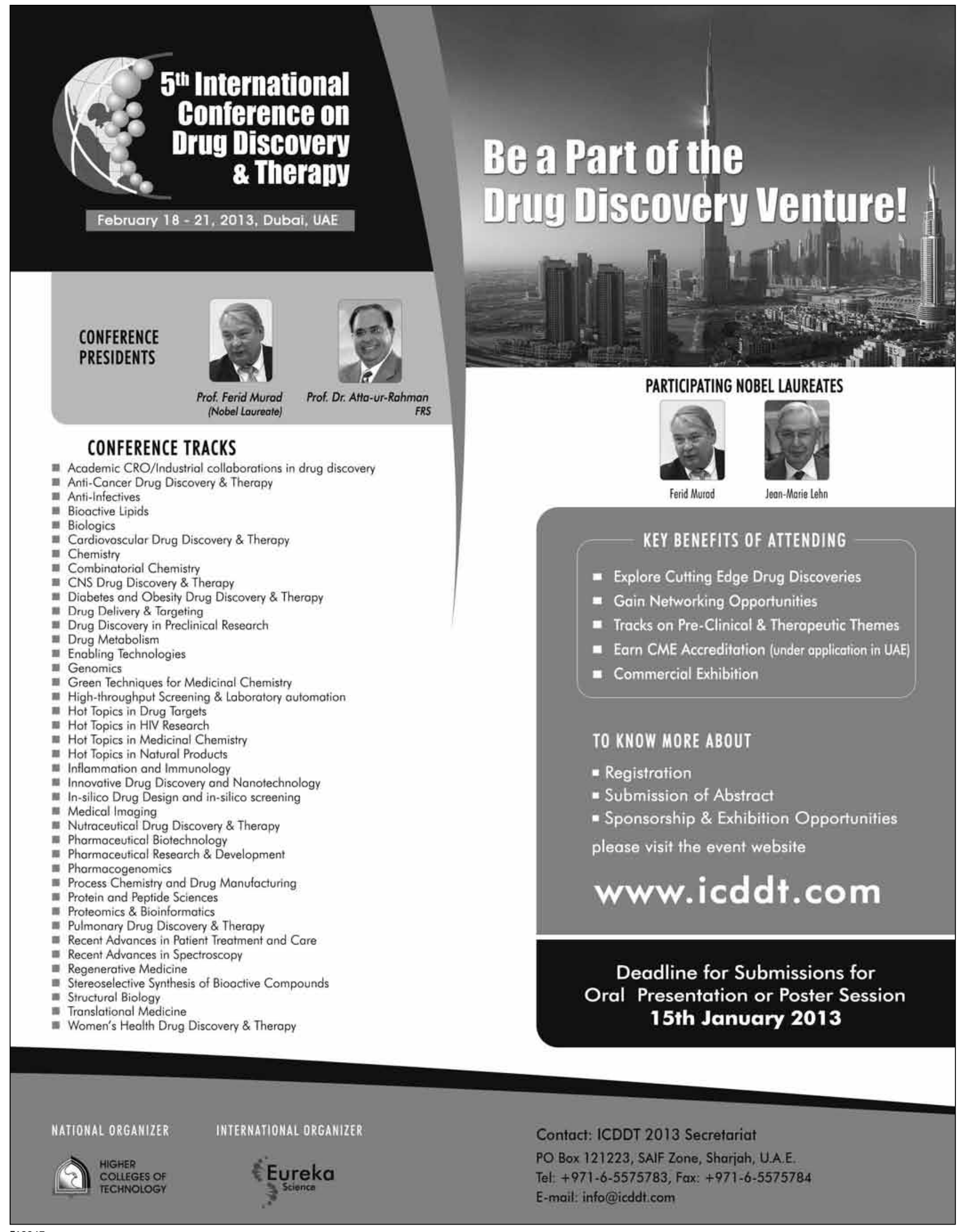




\title{
54. Kongress
}

Deutsche Gesellschaft für

Pneumologie und Beatmungsmedizin e.V.

\section{0.-23. März 2013, Convention Center Messe Hannover}

\section{„Pneumologie im Wandel"}

\author{
Kongresspräsident \\ Prof. Dr. med. Ulrich Costabel \\ Abteilung Pneumologie/Allergologie \\ Ruhrlandklinik - Universitätsklinik \\ Tüschener Weg 40 \\ 45239 Essen \\ Tel. +49 (0) 201/433 4021 \\ Fax +49 (0) 201/433 4029 \\ E-Mail ulrich.costabel@ruhrlandklinik.uk-essen.de
}
Kongresssekretariat Martina Voßwinkel
Tel. +49 (0) 201/433 4021
Fax +49 (0) 201/433 4029
E-Mail martina.vosswinkel@ruhrlandklinik.uk-essen.de

Kongressorganisation Agentur KONSENS GmbH

Postfach 1337

59356 Werne

Tel. +49 (0) 23 89/52 75-0

Fax +49(0) 23 89/52 75-55

E-Maildgp@agentur-konsens.de

www.dgp-kongress.de 


\section{Joint Annual Meeting of the}

\section{Swiss Society for Allergology and Immunology and the Swiss Respiratory Society}

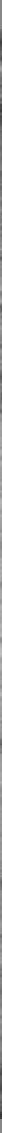

\section{7-19 April 2013 \\ Kursaal Bern/Switzerland}

\section{www.ssai-sgp2013.ch}

SOCIÉTÉ SUISSE D'ALLERGOLOGIE ET D'IMMUNOLOGIE SSAI
SCHWEIZ. GESELLSCHAFT FÜR ALLERGOLOGIE UND IMMUNOLOGIE SGAI
SWISS SOCIETY FOR ALLERGOLOGY AND IMMUNOLOGY SSAI

SCHWEIZERISCHE GESELLSCHAFT

FÜR PNEUMOLOGIE SOCIÉTÉ SUISSE DE PNEUMOLOGIE

SOCIETÀ SVIZZERA DI PNEUMOLOGIA $\because \because \because \because \because$ AEROBIOLOGY

$\because \because \because \because \because$ SEHWEITERSICHE GESEUISCHAFT
SOCGIE SUISSE
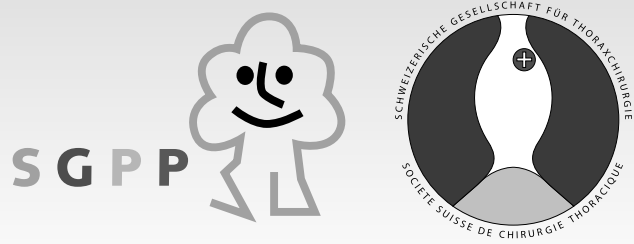


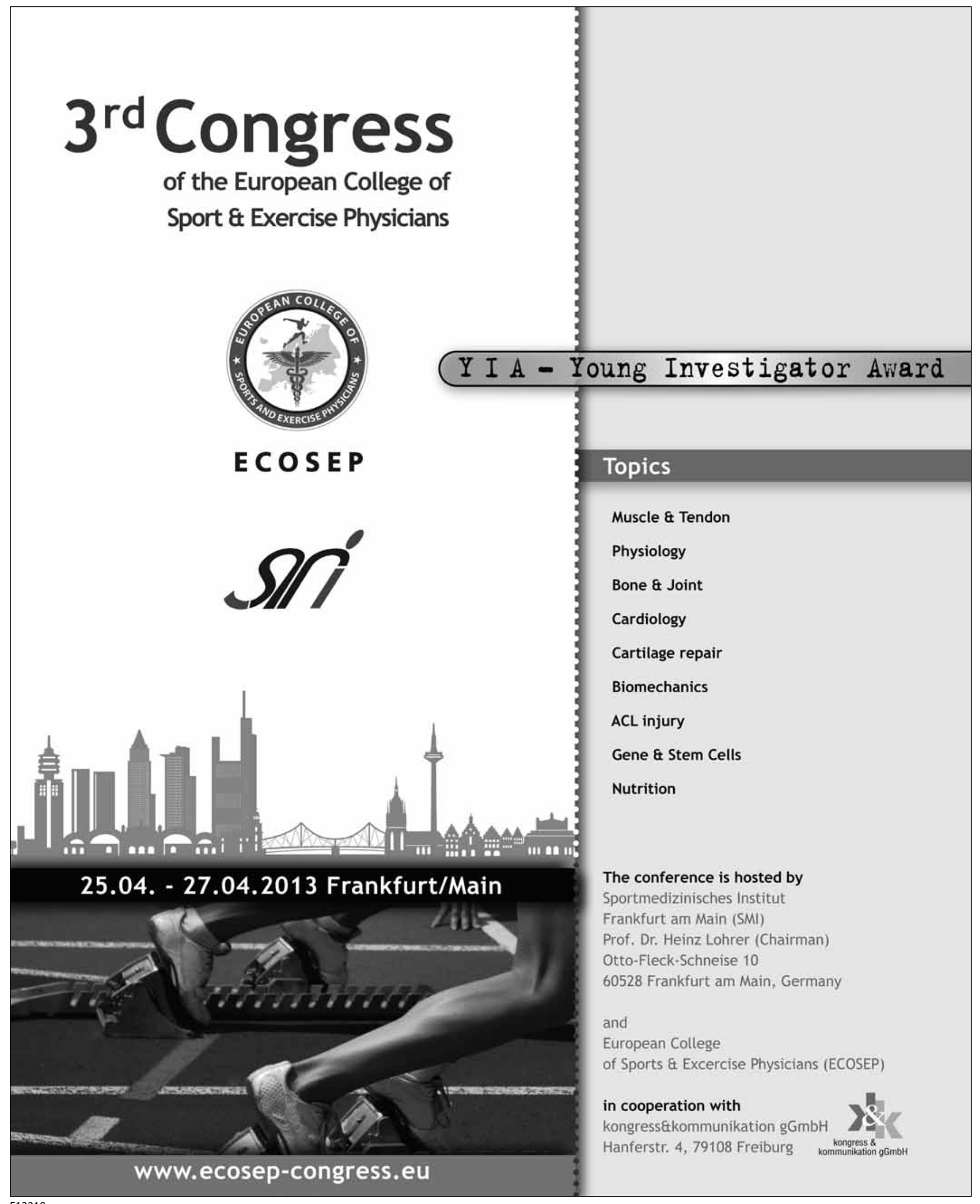




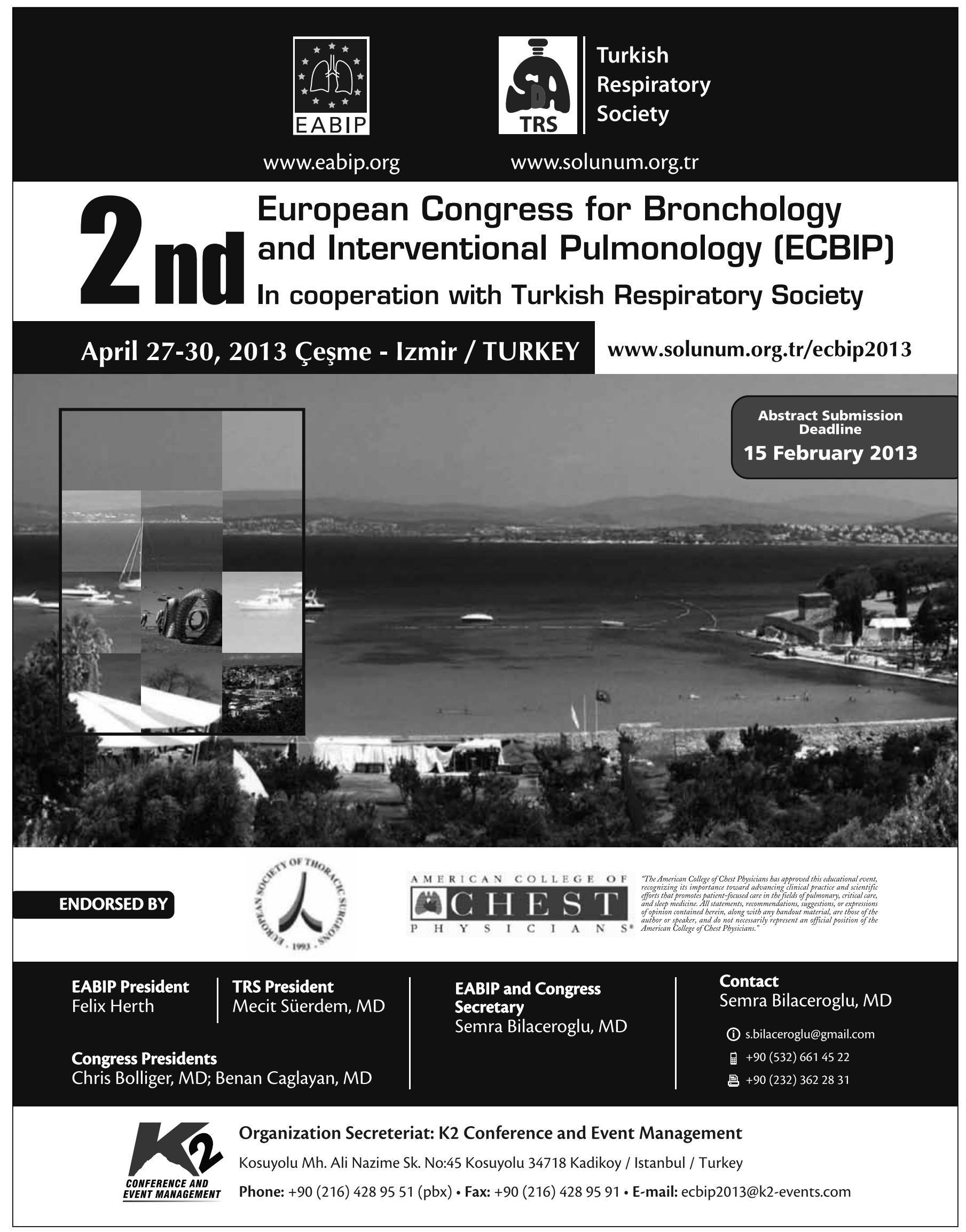




\section{With contributions by some of the most well-known specialists in tuberculosis research}

\section{Antituberculosis Chemotherapy}

\section{Antituberculosis Chemotherapy}

Edators
Peter R. Donald
Paul D. van Helde

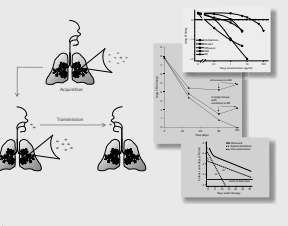

KARGER

\author{
Editors \\ Peter R. Donald \\ Paul D. van Helden
}

Tuberculosis (TB) remains one of the major infectious diseases of mankind although drugs for its treatment have been available for nearly 60 years. The standard short-course 6-month regimen used since about 1980 has helped to save millions of lives, but co-infection with HIV has had a devastating effect on the epidemic, and multidrug-resistant TB is a growing problem, particularly in communities with a high incidence of HIV. Following the declaration by the WHO in the early 1990s that TB was a 'global health emergency', interest in TB research and the development of new drugs has increased significantly.

This volume reviews anti-TB chemotherapy with the emphasis on the actions and pharmacology of existing drugs and the development and evaluation of new agents. A close look is taken at new research regarding our existing drugs by some of the best-known specialists in the field, and historical aspects of these agents are reviewed from a modern perspective. The prospects for the introduction of new drugs and different approaches of how to assess them in adults and in children are discussed in detail. Several papers address the problems associated with drug resistance, its spread and diagnosis.

Compiled by two editors from Cape Town, which has a particularly high incidence of TB and is a centre of tuberculosis research, this publication is an indispensable reference for anyone involved in the management of TB either as a researcher, clinician or administrator, and those working in drug development.

\section{Contents}

\section{Retrospectoscope}

History of Drug Discovery: Early Evaluation

Studies and Lessons Learnt from Them:

Ahmad, Z.; Makaya, N.H.; Grosset, J.

Tuberculosis Treatment Trials Past and Present:

Old and New Challenges: Nunn, $\boldsymbol{N}$.

\section{Present Treatment}

The Rifamycins: Renewed Interest in an Old Drug Class: Burman, W.; Dooley, K.E.; Nuermberger, E.L.

Isoniazid Pharmacokinetics and Efficacy in Adults and Children: Donald, P.R.; Schaaf, H.S.

Recent Developments in the Study of Pyrazinamide: An Update: Mitchison, D.A, Zhang, Y.

Experience with Phase III Clinical Trials of Antituberculosis Drugs and Regimens: Conclusions and Lessons for the Future: Jindani, $\boldsymbol{A}$.

Fluoroquinolones in the Management of Tuberculosis: Singh, K.P.; Gillespie, S.H.

Current Standard Treatment: Vernon, A.A.

Tuberculosis Recurrence: Exogenous or Endogenous?: Williams, $\boldsymbol{M}$. et al.

Second-Line Antituberculosis Drugs: Current Knowledge, Recent Research Findings and Controversies: Schaaf, H.S. et al.

Acquisition, Transmission and Amplification of Drug-Resistant Tuberculosis: Müller, B. et al.

The Treatment of Tuberculosis in Children: Cruz, A.T.; Starke, J.R.

www.karger.com/prrer
The Future

Issues and Challenges in the Development of Novel Tuberculosis Drug Regimens: Erondu, $\boldsymbol{N}$.; Ginsberg, $A$.

Drug Resistance in Mycobacterium tuberculosis: Molecular Mechanisms and Laboratory Susceptibility Testing: Böttger, E.C.

The Role of the Mouse Model in the Evaluation of New Antituberculosis Drugs: Nuermberger, E.L.

Current Issues in Tuberculosis Pharmacokinetics: Egelund, E.F.; Peloquin, C.A.

Pharmacological Considerations of Antitubercular Agents in Children: Goldman, J.L. et al.

Pharmacogenetics of Antituberculosis Drugs: Aarnoutse, $R$.

Interactions between Antituberculosis and Antiretroviral Agents: Mcllleron, H.; Khoo, S.H.

Diabetes Mellitus and Tuberculosis Treatment: Ruslami, R.; van Crevel, $R$.

Early Bactericidal Activity of Antituberculosis Agents: Diacon, A.H.; Maritz, J.Z.; Donald, P.R.

Assessment of Whole-Blood Bactericidal Activity in the Evaluation of New Antituberculosis Drugs: Wallis, R.S.

Serial Sputum Colony Counting in Drug Development: Sloan, D.; Davies, $\mathbf{G}$.

The Evaluation of New Antituberculosis Drugs in Children: McNeeley, D.F. et al.

A New Era in Tuberculosis Treatment: What Does the Future Hold?: Duncan, $\boldsymbol{K}$.

Author Index / Subject Index

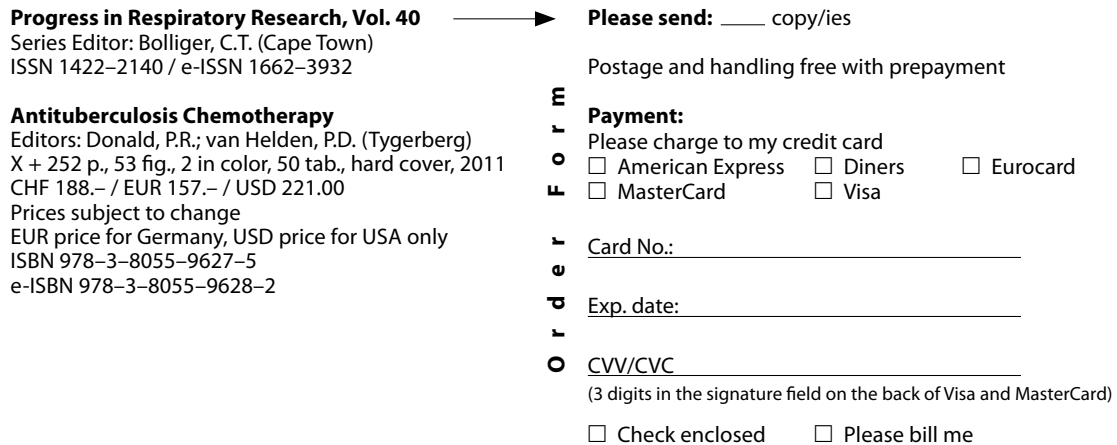

\section{Please send: _ c copy/ies}

Postage and handling free with prepayment

E

Payment:

Please charge to my credit card

- $\square$ American Express $\square$ Diners $\square$ Eurocard

ᄂ $\quad$ MasterCard

- Card No.

$\boldsymbol{\sigma}$

Exp. date

政

- $\mathrm{CVV} / \mathrm{CVC}$

( 3 digits in the signature field on the back of Visa and MasterCard)

$\square$ Check enclosed $\quad \square$ Please bill me

Orders may be placed with any bookshop, subscription agency, directly with the publisher or through a Karger distributor.

\section{Fax: +41 613061234}

S. Karger AG, P.O. Box, CH-4009 Basel (Switzerland)

E-Mail orders@karger.ch, www.karger.com

Name/Address: 


\section{OLYMPUS}

\section{EVIS EXERA III}

Your Vision, Our Future

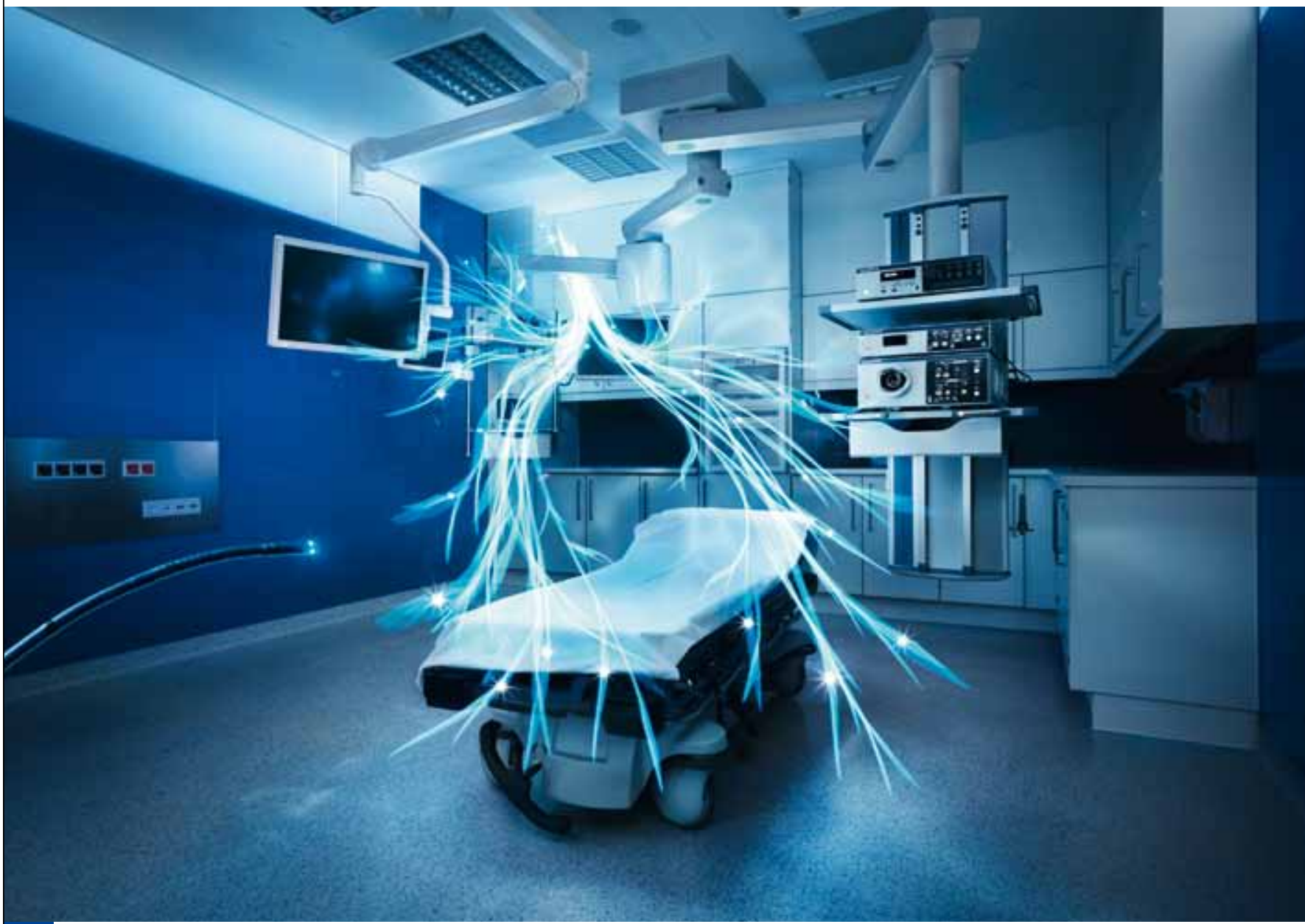

\section{EVIS EXERA III}

\section{Advancing the Art of Bronchoscopy.}

In the pursuit of the perfect bronchoscopy system, Olympus introduces EVIS EXERA III as the next milestone towards improved clinical outcomes.

For more information, please visit www.olympus-europa.com/EXERA3

OLYMPUS EUROPA HOLDING GMBH

Postbox 1049 08, 20034 Hamburg, Germany | Tel. +49 40 23773-0 | www.olympus-europa.com 


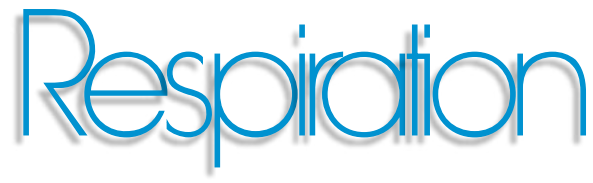

Thematic Review Series 2012

441 Treating the Small Airways

Usmani, O.S. (London)

Clinical Investigations

454 Exercise Dependence of N-Terminal Pro-Brain Natriuretic Peptide in Patients with Precapillary Pulmonary Hypertension

Grachtrup, S.; Brügel, M.; Pankau, H. (Leipzig); Halank, M. (Dresden); Wirtz, H.; Seyfarth, H.-J. (Leipzig)

461 Detection of Interstitial Lung Disease in Systemic Sclerosis through Partitioning of Lung Transfer for Carbon Monoxide

Pernot, J.; Puzenat, E.; Magy-Bertrand, N.; Manzoni, P.; Gondouin, A.; Bourdin, H.; Simon-Rigaud, M.-L.; Regnard, J.; Degano, B. (Besançon)

469 Predictors of Successful Decannulation Using a Tracheostomy Retainer in Patients with Prolonged Weaning and Persisting Respiratory Failure Budweiser, S. (Rosenheim/Donaustauf); Baur, T. (Donaustauf); Jörres, R.A. (Munich); Kollert, F. (Donaustauf/Freiburg); Pfeifer, M. (Donaustauf/Regensburg); Heinemann, F. (Donaustauf)

477 Daytime Measurements Underestimate Nocturnal Oxygen Desaturations in Pulmonary Arterial and Chronic Thromboembolic Pulmonary Hypertension Hildenbrand, F.F.; Bloch, K.E.; Speich, R.; Ulrich, S. (Zurich)
485 Characterization of Maximal Respiratory Pressures in Healthy Children

Cox, D.W.; Verheggen, M.M.; Stick, S.M.; Hall, G.L. (Perth, W.A.)

492 Clinical Characteristics and Outcomes of Patients with Clinically Unsuspected Pulmonary Embolism versus Patients with Clinically Suspected Pulmonary Embolism Shteinberg, M.; Segal-Trabelsy, M.; Adir, Y.; Laor, A. (Haifa); Vardi, M. (Haifa/Boston, Mass.); Bitterman, H. (Haifa)

Interventional Pulmonology

501 Simultaneous Computed Tomography-Guided Biopsy and Radiofrequency Ablation of Solitary Pulmonary Malignancy in High-Risk Patients

Schneider, T.; Puderbach, M.; Kunz, J.; Bischof, A.;

Giesel, F.L.; Dienemann, H.; Herth, F.J.F.; Schnabel, P.A.; Safi, S.; Hoffmann, H.; Heussel, C.P. (Heidelberg)

Basic Science Investigations

509 N-Acetylcysteine Downregulation of Lysyl Oxidase Activity Alleviating Bleomycin-Induced Pulmonary Fibrosis in Rats

Li, S.; Yang, X. (Guangzhou); Li, W. (Boston, Mass.); Li, J.; Su, X.; Chen, L.; Yan, G. (Guangzhou)

Novel Insights from Clinical Practice

518 Mediastinal Lymphangioma Treated Using Endobronchial Ultrasound-Guided Transbronchial Needle Aspiration

Choi, S.H.; Kim, L.; Lee, K.-H.; Cho, J.H.; Ryu, J.-S.; Kwak, S.M.; Nam, H.-S. (Incheon)

522 Congress Calendar

after 522 Contents Vol. 84, 2012 